\title{
1 \\ The Evolving Field of Organizational Learning and Knowledge Management
}

\author{
MARK EASTERBY-SMITH \\ AND MARJORIE A. LYLES
}

Organizational learning (OL) and knowledge management (KM) research has gone through dramatic changes in the last twenty years and, without doubt, the field will continue to change in the next ten years. Our research suggests that Cyert and March were the first authors to reference organizational learning in their publication of 1963 . It was just twenty years ago that a conference was held at Carnegie Mellon University to honor March and his contribution to the field of organizational learning. Many of these presentations were published in a special issue of Organization Science in 1991.

Since that time we have seen a rapid expansion in the number of journal articlesboth academic and practitioner - devoted to organizational learning. Fields such as information technology, marketing and human resources have also jumped on the bandwagon. Doctoral programs are including seminars on organizational learning, and MBA courses on organizational learning are appearing. All of this reflects acceptance of the concept that organizations have knowledge, do learn over time, and consider their knowledge base and social capital as valuable assets. It also reaffirms the legitimacy of research on organizational learning and its practical applications to organizations.

The first edition of this Handbook was published in 2003 but most chapters were completed in 2001 or 2002. Our first edition was widely used and it was clear - given the advancement of the field - that a second edition was necessary. Some people might claim that it is foolhardy to seek to cover the full range of the literature within one volume. Our intent is to provide a resource that is useful to academics, practitioners, and students who want an overview of the current field with full recognition that - to our delight - the field continues to have major impact on research and management practices. Our response is 
to highlight four features of the current literature, which provide a general rationale for compiling this Handbook.

First is the novelty and speed of development of the field. Overall, there was very little activity before 1990, and in some sub-areas almost everything dates after 1995. The speed of development, coupled with the lead times of publishing, means it is hard to develop a cumulative sense to the field where studies and publications are able to build systematically on previous work. Many of the chapter authors show how the present position has evolved from prior work, and then proceed to speculate on potential future directions (for example, see Argote, Denomme, and Fuchs, Chapter 29; and Van Wijk, van den Bosch, and Volberda, Chapter 22).

The second feature is the increasing diversity and specialization of the field. This has led to tighter definitions and the isolation of problems such as the political implications of organizational learning and knowledge management; it has also led to developments taking place in parallel which result in limited awareness of what is happening elsewhere at the same time. There is therefore a need to locate different sub-areas in relation to each other, so that overlaps and potential areas of synergy can be identified. In preparing the chapters of this book the authors have been aware of topics of other chapters and had access to the chapter drafts so that they could also identify potential commonalities and differences, whether there are overlaps of subject material, similar theoretical roots, or shared problem areas. This also implies a need for some mapping exercises, and several of the chapters (in addition to this one) aim to do just that (for example, see Shipton and DeFillippi, Chapter 4; and Vera, Crossan, and Apaydin, Chapter 8).

The third feature is that debates and arguments have started to flourish largely as a consequence of this diversity. Debates have focused around the definition of terms and the meaning of concepts, the appropriateness of methods of inquiry, ways of influencing learning processes within organizations, and the purposes to which we should put our knowledge of organizational learning and knowledge management. Because they lead to clarification of terms, sharpening of distinctions, and development of new ideas, these debates are invaluable. Consequently, we have encouraged authors to identify ongoing debates in their areas; and in a number of places we have juxtaposed chapters that represent different perspectives on particular contemporary debates.

Fourth, despite the growing diversity we have also been surprised at the number of citations that appear repeatedly across the chapters of the Handbook, which suggests that there still remains considerable commonality in the field. If we reach back to some of the earlier papers, there are several common points of departure, which may have become a form of 'tacit knowledge' that underlies the work of most scholars. Accordingly we devote much of this chapter to looking at the sources of key concepts, and to the works that have had a disproportionate influence on the evolution of the field. We see these as being similar to the watersheds of rivers which provide essential starting points for distinct streams, but which may subsequently be forgotten as the downstream rivers gather both strength and importance.

This opening chapter has three main sections. In the first section we offer a preliminary mapping of the field that is covered by the Handbook, which is elaborated in the chapters that follow. In the second section we present an analysis of the citations given by the chapters in this Handbook. In order to give an indication of changing priorities since the first edition was published we have divided this into two separate tables: Table 1.1 covers the 
references that predate 2000 and Table 1.2 covers references after 2000. There are 1160 citations to work predating 2000 out of a total of over 2229 references across the twentynine chapters of the book. In the third section we develop the theme of watersheds by focusing on the older publications, some of which score well in our analysis of citations, and all of which appear to have had a significant impact on the evolution of the fields of organizational learning and knowledge management.

\section{The Field and Scope of the Handbook}

For reasons of space, the title of the handbook refers to organizational learning and knowledge management; but two other important topics, 'the learning organization' and 'organizational knowledge', are also covered here. At first glance they may all seem very similar; but there are a number of important distinctions which we will explain below. The distinction between the first two terms was clearly articulated by Tsang (1997) to the extent that organizational learning refers to the study of the learning processes of and within organizations, largely from an academic point of view. The aims of such studies are therefore primarily to understand and critique what is taking place. On the other hand the learning organization is seen as an entity, an ideal type of organization, which has the capacity to learn effectively and therefore to prosper. Those who write about learning organizations generally aim to understand how to create and improve this learning capacity, and therefore they have a more practical impact and a performance agenda. We have gathered together papers in Part II of this volume, which reflect different aspects of the domain covered by these two terms.

A similar distinction can be made between the terms organizational knowledge and knowledge management. Those who write about the former often adopt a philosophical slant in trying to understand and conceptualize the nature of knowledge that is contained within organizations. Hence many of the discussions relate to distinctions between individual and organizational knowledge, whether the distinction between tacit and explicit knowledge is useful, or whether knowledge is a strategic advantage or asset. Also covered is how and what knowledge is shared and how knowledge is stored. Those who write about the latter generally adopt a technical approach aimed at creating ways of measuring, disseminating, storing, and leveraging knowledge in order to enhance organizational performance. The role and design of information technology is also important to such discussions. Part III of the Handbook considers issues in the domain of organizational knowledge and knowledge management (for example, see Almeida, Hohberger, and Parada, Chapter 18; Teece, Chapter 23; Zollo and Verona, Chapter 24; and Ahuja and Novelli, Chapter 25).

Part IV recognizes the importance of organizational learning and knowledge within the expanding international context of research in this area. The chapters in this section of the Handbook address areas of intercultural exchange, international context, and learning across borders.

In Figure 1.1 we offer an initial mapping of these four terms, based on the dichotomies of theory-practice and content-process. The first of these dichotomies follows the concerns of academics against those of practitioners, as described above. Even this is not necessarily straightforward. For example, a critical study of a learning organization would fit into the organizational learning box, and a study of the way knowledge is constructed 


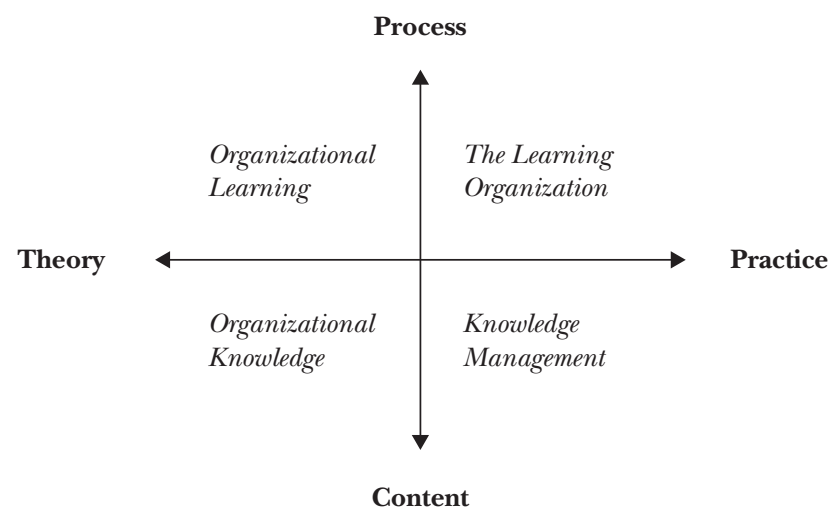

Figure 1.1 Mapping of Key Topics in the Handbook

within corporate knowledge management systems would belong to the organizational knowledge box.

The second dichotomy, the distinction between learning and knowledge, also seems fairly obvious: knowledge being the stuff (or content) that the organization possesses, and learning being the process whereby it acquires this stuff. Again, things are not quite so simple, as several of the chapters will demonstrate. For example, some chapters build on the paper by Cook and Brown (1999) which distinguishes between the epistemologies of possession and practice. In this case 'possession' fits well with the view of knowledge as content, but the epistemology of practice (or knowing) fits more closely with the process of learning from experience. We mention these potential limitations in passing because we still believe that it is valuable to start with some clear organizing principles, as an initial map for the reader. But we would also hope that those who get to the end of the book will become very clear about the inadequacies of such dichotomies!

There are also a number of themes and issues, which cut across the whole field, and therefore touch on all four quadrants of Figure 1.1. Some of these are fundamental issues about the nature of knowledge (Tsoukas, Chapter 21) and the processes of learning (Vera et al., Chapter 8); others relate to the role played by culture (Taylor and Osland, Chapter 26), emotion (Vince and Gabriel, Chapter 15), forgetting (de Holan and Phillips, Chapter 20), social identity (Child and Rodrigues, Chapter 14), and organizational identity (Corley et al., Chapter 16).

Many of the chapters review and update key concepts such as knowledge sharing (Salk and Simonon, Chapter 27), dominant logic (Bettis et al., Chapter 17), communities of practice (Plaskoff, Chapter 10; von Krogh, Chapter 19), teams (Roloff, Woolley, and Edmondson, Chapter 12), fluidity (Calhoun et al., Chapter 11), knowledge assets (Teece, Chapter 23), knowledge structures (Ahuja and Novelli, Chapter 25), absorptive capacity (Van Wijk, Van den Bosch, and Volberda, Chapter 13), and dynamic capabilities (Zollo and Verona, Chapter 24). Not only is it possible to locate these concepts on the general map of Figure 1.1, but it is also worth noting that they are often informed by different disciplinary and ontological assumptions (Easterby-Smith, 1997). That is why we have grouped a number of chapters into Part I, which considers the disciplinary perspectives 
underlying current developments in the field. We therefore hope that these chapters will enable readers to locate more clearly the different papers in subsequent parts of the book.

This brings us to the next section of the initial chapter. On the grounds that knowledge of the past is useful in making sense of the present, our aim here is to consider some of the formative influences in the field from a historical perspective. Thereby we hope to explain both similarities and differences between distinct parts of the field.

\section{Major Sources}

If we start with the four terms in Figure 1.1, although all of them are relatively new, some are newer than others. Thus, the idea of knowledge management only emerged in the mid-1990s, whereas the first references to organizational learning appeared as far back as the early 1960s (Cyert and March, 1963; Cangelosi and Dill, 1965). But all four areas draw on literature and ideas that are older than their immediate concerns, and in a number of places there are overlaps between these initial sources.

Moreover, the field as a whole has been characterized by sudden surges of interest in particular topics, often followed soon after by rapid decline. (See Calhoun, Starbuck, and Abrahamson, Chapter 11, for further discussion of fads and fashions). These surges can often be explained by the changes in the business or technological environment. But literature also plays a significant part, and a number of books or papers have managed to capitalize on latent interest which then creates a major sub-industry in its own right. One obvious example is the book by Peter Senge (1990) which is one of the most cited texts in this volume. Although Senge was not the first person to coin the term 'learning organization,' it was the publication of his book which led to international awareness of the learning organization across both academic and practitioner communities. Thereafter, many large companies started claiming they were learning organizations, or that they were aspiring to this status; academics rushed to identify the characteristics of learning organizations, or to critique and deconstruct the very concept. As such, the publication of Senge's book represents a watershed, in the same way that Peters and Waterman (1982) represented a watershed for academics, consultants, and practitioners in the previous decade.

Our aim now is to examine systematically the chapters in this book to see if there are patterns and trends that can be discerned. We do this by first looking at the citations that predate 2000, where the content of the item has some relevance to the fields of organizational learning and management. Then we look at citations to papers that appeared from 2000 onwards. This gives an indication of the rises and falls in the influence of different authors over the last decade.

In Table 1.1 we list the authors of books or papers according to how many of the chapters in this Handbook have cited them. For each cited work we give the author names and date, but we do not provide full bibliographical details at the end of this chapter because all are cited in subsequent chapters.

There are a few points to note about this table. First, the list provides most of the names one would expect to see. If we take the total number of citations for authors, then the leading figures in the field are March, Nonaka, Argyris, Senge, Szulanski, and Huber, along with the pairs of Lave and Wenger, Brown and Duguid, Nelson and Winter, Cohen and Levinthal, Cook and Brown, and Kogut and Zander. Second, the dominance of the 
Table 1.1 References prior to 2000 most cited in this Handbook

\section{2 hits (1)}

Nonaka and Takeuchi (1995)

10 hits (2)

Huber (1991)

Kogut and Zander (1992)

8 hits (5)

Argyris and Schön (1978)

Cohen and Levinthal (1990)

Cook and Brown (1999)

Nelson and Winter (1982)

Teece, Pisano, and Shuen (1997)

6 hits (4)

Grant (1996)

Lane and Lubatkin (1998)

Nonaka (1994)

Simon (1991)

4 hits (14)

Argote (1999)

Barney (1991)

Daft and Weick (1984)

Darr, Argote, and Epple (1995)

Davenport and Prusak (1998)

Garvin (1993)

Lyles and Schwenk (1992)

Mowery, Oxley, and Silverman (1996)

Nahapiet and Ghoshal (1998)

Polanyi (1962)

Powell, Koput, and Smith-Doerr (1996)

Simon (1947)

Walsh and Ungeson (1991)

Zander and Kogut (1995)
11 hits (1)

Brown and Duguid (1991)

9 hits (6)

Lave and Wenger (1991)

Levitt and March (1988)

March (1991)

Senge (1990)

Szulanski (1996)

Wenger (1998)

7 hits (2)

Cyert and March (1963)

Fiol and Lyles (1985)

\section{5 hits $(8)$}

Alavi and Leidner (1999)

Cook and Yanow (1993)

Dyer and Singh (1998)

Gherardi, Nicolini, and Odella, (1998)

Lyles and Salk (1996)

March and Simon (1958)

Penrose (1959)

Polanyi (1966)

\section{3 hits $(33)$}

Almeida and Kogut (1999)

Argote, Beckman, and Epple, (1990)

Barnard (1938)

Bettis and Prahalad ( 1995)

Brown and Duguid (1998)

Burt (1992)

Doz (1996)

Easterby-Smith (1997)

Easterby-Smith, Snell, and Gherardi(1998)

Galunic and Rodan (1998)

Hamel (1991)

Hansen, Nohria, and Tierney (1999)

Inkpen and Crossan (1995)

Inkpen and Dinur (1998)

Jaffe, Trajtenberg, and Henderson (1993) 
Table 1.1 (Continued)

\begin{tabular}{|c|c|}
\hline & $\begin{array}{l}\text { Khanna, Gulati, and Nohria (1998) } \\
\text { Kogut (1988) } \\
\text { Lave (1988) } \\
\text { Lyles (1988) } \\
\text { Miner and Mezias (1996) } \\
\text { Nicolini and Meznar (1995) } \\
\text { Nonaka (1998) } \\
\text { Orr (1996) } \\
\text { Simonin (1999) } \\
\text { Spender (1996) } \\
\text { Teece (2007) } \\
\text { Tsoukas (1996) } \\
\text { Wegner (1986) } \\
\text { Weick (1991) } \\
\text { Weick and Roberts (1993) } \\
\text { Williamson (1985) }\end{array}$ \\
\hline $\begin{array}{l}2 \text { hits } \\
102 \text { further papers }\end{array}$ & $\begin{array}{l}1 \text { hit } \\
982 \text { further papers }\end{array}$ \\
\hline $\begin{array}{l}\text { Total number of references prior to } \\
2000 \text { cited in this Handbook: } 1160\end{array}$ & $\begin{array}{l}\text { Total number of references cited in } \\
\text { the Handbook: } 2229\end{array}$ \\
\hline
\end{tabular}

top publications is balanced by considerable diversity once one gets down to the level of detail. Thus, although the top ten were cited repeatedly, nearly half of the papers were only cited once or twice. This is because many of the authors are working in specialist areas, which have limited overlap with others.

A comparison between the present analysis and the same analysis conducted for the first edition shows that these classics of the learning literature are still important, but that their relative influence has diminished somewhat. Thus Nonaka and Takeuchi (1995), Brown and Duguid (1991), Huber (1991), Kogut and Zander (1992), and Nelson and Winter (1982) are still there, but a few other papers have grown in significance, notably Lave and Wenger (1991), Teece, Pisano, and Shuen (1997), and Wenger (1998).

Table 1.2, which covers the period from 2000-2010 provides an indication of trends in the field since the first edition was written. It shows the continuing dominance of some established scholars, notably Nonaka, and Brown and Duguid, but also the rise of some new stars including Argote and Ingram, Gherardi, von Krogh, Carlile, and Orlikowski. The topics covered by these authors demonstrate the growing interest in organizational knowledge creation and the social processes underlying organizational learning and knowledge. 
Table 1.2 References for 2000-2010 cited in the Handbook

\begin{tabular}{|c|c|}
\hline $\begin{array}{l}8 \text { hits }(1) \\
\text { Brown and Duguid (2001) }\end{array}$ & 7 hits $(0)$ \\
\hline $\begin{array}{l}6 \text { hits }(1) \\
\text { Argote and Ingram (2000) }\end{array}$ & $\begin{array}{l}\mathbf{5} \text { hits }(2) \\
\text { Gherardi (2006) } \\
\text { von Krogh, Ichijo, and Nonaka, (2000) }\end{array}$ \\
\hline $\begin{array}{l}\mathbf{4} \text { hits }(4) \\
\text { Carlile (2002) } \\
\text { Nonaka and von Krogh (2009) } \\
\text { Orlikowski (2002) } \\
\text { Zollo and Winter (2002) }\end{array}$ & $\begin{array}{l}3 \text { hits (28) } \\
\text { Ahuja (2000) } \\
\text { Ahuja and Katila (2001) } \\
\text { Almeida and Phene (2004) } \\
\text { Argote, McEvily, and Reagans (2003) } \\
\text { Baum, Calabrese, and Silverman (2000) } \\
\text { Brown and Duguid (2000) } \\
\text { Carlile (2004) } \\
\text { Easterby-Smith, Grossan, and } \\
\quad \text { Nicolini (2000) } \\
\text { Easterby-Smith, Lyles, and Tsang (2008) } \\
\text { Eisenhardt and Martin (2000) } \\
\text { Gavetti, Levinthal, and Rivkin (2005) } \\
\text { Gourlay (2006) } \\
\text { Gupta, and Govindarajan (2000) } \\
\text { Lane, Salk and Lyles (2001) } \\
\text { Menon and Pfeffer (2003) } \\
\text { Nonaka, von Krogh, and Voelpel (2006) } \\
\text { Obstfeld (2005) } \\
\text { Oddou, Osland, and Blakeney (2009) } \\
\text { Rashman, Withers, and Hartley (2009) } \\
\text { Reagans and McEvily (2003) } \\
\text { Rosenkopf and Almeida (2003) } \\
\text { Rosenkopf and Nerkar (2001) } \\
\text { Teece (2007) } \\
\text { Tsai (2001) } \\
\text { Volberda, Foss, and Lyles (2010) } \\
\text { Wasko and Faraj (2005) } \\
\text { Zollo and Singh (2004) }\end{array}$ \\
\hline $\begin{array}{l}2 \text { hits } \\
93 \text { further papers }\end{array}$ & $\begin{array}{l}1 \text { hit } \\
940 \text { further papers }\end{array}$ \\
\hline $\begin{array}{l}\text { Total number of references } \\
\text { included in analysis: } 1069\end{array}$ & $\begin{array}{l}\text { Total number of references cited in the } \\
\text { Handbook: } 2229\end{array}$ \\
\hline
\end{tabular}




\section{WATERSHEDS}

As suggested above, we are using the term 'watershed' to indicate a significant turningpoint in the development of the subject area. In making sense of key watersheds we need to take account of (a) the absolute frequency of citation, (b) the timing of each publication, (c) the topic of the paper that does the citing, and (d) the text in which the citation is embedded. Given the natural tendency of academics to cite more recent work, there is a good case for giving extra weight to some of the older works which have been cited, especially where they are identified by authors working in different fields.

On this basis we may identify three main groups of literature as the timeline moves forward: (i) classic works that pre-date the identification of the ideas of organizational learning and knowledge management per se, (ii) foundational works which represent some of the first writings that set the agenda for subsequent work, and (iii) popularizing works which have acted as the most visible watersheds in the development of the field. It is important to note in passing that we do not regard the third term as being in any way pejorative; indeed, some of the 'popularizing' works were highly scholarly and all of them managed to generate streams of extremely valuable work. It is not possible to give single time-bands within which the three groups of literature appeared because different sub-areas have emerged at different times and at different rates; hence, the relevant watersheds come at slightly different times. We start with classic works which are presented for the whole field; we then consider separately the time lines within each of the four sub-areas defined at the outset of this chapter.

\section{Classic works}

Here we identify four main authors who have had a significant influence and who were active before the earliest mentions of terms such as organizational learning appeared: John Dewey, Michel Polanyi, Edith Penrose, and Frederick Hayek. They are not the most frequently cited in the present volume, partly because they have been overlaid by more recent authors (and as academics we are encouraged to focus more on recent publications than on classic works). Nevertheless, each of them has a substantial rating in the ISI Web of Science (running to several thousand for Dewey, Polanyi, and Hayek). We comment briefly here on their contributions primarily in the light of chapters within this Handbook, and in a few cases we will also refer to other key works in the field, including those listed in Table 1.1.

Dewey is the only one of these authors who explicitly focused his attention on learning. His ideas of learning from experience fit most easily into models of individuals' learning within organizations, and the notion of iterations between experience and reflection is frequently seen to underlie action learning, which is one of the key tools of the learning organization (Pedler, Boydell, and Burgoyne, 1989). Dewey's view that learning takes place through social interaction and yet cannot be passed from person to person as if it were a physical object is also seen to underlie the social learning perspective (Brandi and Elkjaer, Chapter 2). Other authors who take a social constructionist approach to organizational knowledge (Cook and Brown, 1999; Nicolini and Meznar, 1995; Shipton and DeFillippi, Chapter 4) follow Dewey's ideas, while Nonaka and Takeuchi (1995) acknowledge the 
impact of his philosophical contribution to 'pragmatism' in asserting that there cannot be a clear distinction between the observer and the observed.

Polanyi is best known for his distinction between tacit and explicit knowledge. The key idea of 'tacitness' has parallels to Dewey's experiential learning, because it is something that is held within the individual. Naturally, there are many different interpretations of what this all means. One version of tacit knowledge is that it is conscious, but not articulated; another version is that it is unconscious and hence inarticulable, as Tsoukas discusses (Chapter 21). Polanyi's ideas are based on philosophical analysis and argument, rather than on any empirical investigation, and of course, some would argue that the notion of tacit knowledge cannot be examined empirically because it is unconscious.

The influence of Polanyi is most evident in contemporary discussions about the nature of organizational knowledge. The idea of tacit knowledge is important for those trying to understand the roots of competitive advantage because it is the unexpressed knowledge and experiences of organizations which provide the unique competencies that cannot be easily replicated by competitors (Barney, 1991). While tacit knowledge may give unique advantages to a company, it also poses problems because it cannot easily be moved across cultural boundaries (Taylor and Osland, Chapter 26), nor is it easy to move between different parts of the same organization (Argote, Denomme, and Fuchs, Chapter 29).

Penrose is cited less frequently, but her ideas on the significance of the internal (human) resources of the firm are fundamental, and as she puts it: 'the dominant role that increasing knowledge plays in economic processes' (1959: 77). Penrose proposes the importance of 'excess resources' within an organization which can lead to innovation, paralleling the need for slack to allow experimentation. There are many other points made by Penrose which mirror those made both by her contemporaries and by recent authors. Thus, in discussing the role of top teams she comments: 'the administrative group is more than a collection of individuals; it is a collection of individuals who have had experience in working together, for only in this way can teamwork be developed' (1959: 46). And 'success depends upon a gradual building up of a group of officials' experiences in working together' (1959: 52). These views anticipate the ideas of social constructionists who emphasize that organizations know more than the sum of the knowledge of individuals within them; they also emphasize the role of experience and the fact that 'Knowledge comes from formal teaching and from personal experience' (1959: 53), which is very close to the distinction that Polanyi was developing at the same time between explicit and personal (tacit) knowledge.

It is not surprising that the work of Hayek is seen to underlie the thinking of those who adopt an economics perspective on organizational learning and knowledge. In particular, his view that one of the fundamental problems of economics is to use the knowledge initially dispersed around different individuals in a way that contributes to producing good decisions for the organization or society as a whole (see, Foss and Mahnke, Chapter 7). But he has also had a wider influence, possibly because his 1945 paper was extensively quoted by March and Simon (1958). Here, the emphasis that he places on the knowledge held by individuals naturally focuses attention on 'the knowledge of the particular circumstances of time and place' (Hayek, 1945: 80), which may be seen to anticipate the current attention given to 'situated' knowledge. Moreover, it starts to provide a methodological justification for the use of qualitative methods which are sensitive to contextual factors, such as narrative method, in trying to understand processes of organizational learning (see Bettis, Wong, and Blettner, Chapter 17, and Hayes, Chapter 5). 
Not only are the contributions of these four authors still recognized by contemporary scholars, but we can also see that their ideas overlapped with each other in several respects. But all of their work contributed to early work in the management field as well as to the invention of the concept of organizational learning.

\section{Organizational learning}

The idea that an organization could learn and knowledge could be stored over time was the key breakthrough, which was first articulated in the book by Cyert and March (1963). Evidently the book was the product of much discussion and debate which had been going on among the team at Carnegie Tech during the 1950s (Augier, 2001) and it was foreshadowed, but not explicitly, by March and Simon (1958). Cyert and March propose a general theory of organizational learning as part of a model of decision making within the firm, and emphasize the role of rules, procedures, and routines in response to external shocks and which are more or less likely to be adopted according to whether or not they lead to positive consequences for the organization. A number of specific ideas were outlined in their book, which were subsequently developed further by other scholars. Noteworthy points in the book are: the idea that it is through 'organizational learning processes (that) . . . the firm adapts to its environment' (1963: 84); the view that 'the firm learns from its experience' (1963: 100); and an early version of the distinction between single and double-loop learning, to wit, An organization... changes its behavior in response to short-run feedback from the environment according to some fairly welldefined rules. It changes rules in response to longer-run feedback according to some more general rules, and so on' (1963: 101/2).

Cyert and March's book is often described as the foundational work of organizational learning, but others made fundamental contributions in the early days as well. Cangelosi and Dill (1965) produced the first publication in which the words 'organizational learning' appeared in the title, and although the paper is based on tendentious data, it already makes a distinct contribution to debates in the field because it starts to argue against the rationality of assumptions underlying the Cyert and March model. It is suggested that the model may be appropriate for established organizations in stable circumstances, but it has limited relevance to organizations developing within dynamic circumstances. Thus, Cangelosi and Dill propose a model based on tensions between individual and organizational levels of learning, which is similar to the notion of organizational learning being a discontinuous process (Argyris and Schön, 1978).

The book by Argyris and Schön (1978) was very important since it laid out the field as a whole very clearly, and their distinction between organizations with and without the capacity to engage in significant learning (Models II and I) received a great deal of attention. In it, the authors take a different critique of the assumptions of Cyert and March by pointing out that human behavior within organizations frequently does not follow the lines of economic rationality. Both individuals and organizations seek to protect themselves from the unpleasant experience of learning by establishing defensive routines. During the 1970s and 1980s there were a number of other foundational works, such as Hedberg (1981), Shrivastra (1983), Daft and Weick (1984), and Fiol and Lyles (1985), which made important contributions to the definitions of terminology, and to deeper perspectives on organizational learning, such as the distinction between learning and unlearning. 
Perhaps the most significant popularizing force in the study of organizational learning was the publication of the Special Edition of Organization Science in 1991. This contains a number of highly cited articles including March (1991), Huber (1991), Epple, Argote and Devadas (1991), and Simon (1991). These have been very influential, and set the academic research agenda for much of the 1990s. They follow, in the main, the Carnegie tradition which suggests that it is desirable to maximize the efficient use of knowledge in organizations, while recognizing that there are substantial, largely human, antecedents. Many of the chapters in the current volume build explicitly upon their foundations (for example, van Wijk, van den Bosch, and Volberda, Chapter 13; and Teece, Chapter 23).

However, it is also interesting that the same issue of Organization Science included a paper by Brown and Duguid (1991) which has come to represent an alternative tradition that regards the social processes of organizational learning as pre-eminent. This tradition has also been developed through the work of Nicolini and Meznar (1995), Wenger (1998), Brown and Duguid (2000, 2001), and Gherardi (2006). In the current volume it is evident that it underpins the work of authors such as Hayes (Chapter 5), Gherardi (Chapter 4), Taylor and Osland (Chapter 26), von Krogh (Chapter 19), and Plaskoff (Chapter 10). From the early 1990s these two traditions, emphasizing either the efficiency or the social processes of organizational learning, have developed largely independently and have had increasing difficulty in communicating with each other. One of our aims in both editions of this Handbook has been to provide good coverage of both traditions in order to facilitate dialogue and better mutual understanding between the two.

\section{The learning organization}

The idea of the learning organization is of more recent provenance. It emerged towards the end of the 1980s largely on the basis of European work, with UK authors such as Garratt (1987) and Pedler, Boydell, and Burgoyne (1989) making early contributions, although the paper by de Geus (1988), which was published in the Harvard Business Review, brought the concept to wider attention. Nevertheless, the major watershed was the book by Senge (1990) which attracted enormous interest particularly because companies and consultants were searching for new ideas to replace the largely discredited concepts of corporate excellence (Peters and Waterman, 1982). Senge's book was both a foundational work and a popularizer because it rapidly became a key source for academics as well as an inspiration for practitioners. His ideas were highly attractive because they provided the potential for renewal and growth, with an underpinning of both technical and social ideas drawn respectively from the systems dynamics developed by Jay Forrester at MIT, the psycho-dynamic organizational theory developed by Chris Argyris, and process consultation of Ed Schein.

Despite the huge success of Senge's initial book, his perspective has not been widely adopted by the North American academic community (see Calhoun, Starbuck, and Abrahamson, Chapter 11), ${ }^{1}$ and it has continued to be primarily a practitioner affair (for

\footnotetext{
'Even though James March uses the term 'learning organization' in March (1988), it is without the normative implications subsequently associated with the term following the work of Senge (1990).
} 
example, Swieringa and Wierdsma, 1992; Burgoyne, Pedler, and Boydell, 1994; Örtenblad, 2004; Yeo, 2005). The few academics who write in the USA on this issue, for example, Dixon (1994) and Torbert (1994), are often influenced by European ideas, such as the work of Revans (1980) on Action Learning. In the present volume, diBella (Chapter 9) provides valuable updating and development of the concepts related to the learning organization by proposing a more flexible method than that originally laid down by Senge. Plaskoff (Chapter 10) describes strategies for implementing learning in organizations using ideas drawn from the communities of practice literature, and Roloff, Woolley, and Edmondson (Chapter 12) stress the importance of evaluating the contribution of teams.

Early critical work (Coopey, 1995; Coopey and Burgoyne, 2000; Snell and Chak, 1998) raised a number of concerns about the learning organization, including charges that it was politically naïve, contained an ideology that was exploitative of employees, and that it was not necessarily transferable to other cultural contexts. While not necessarily against the idea of the learning organization, later authors stressed that theories and practices needed to include ideas such as power, politics, and culture (Lawrence, et al., 2005; Simm, 2009), and the lack of clear links to business success (Thomas and Allen, 2006). Calhoun, Starbuck, and Abrahamson (Chapter 11) also point to the difficulty in demonstrating the benefits of the learning organization and discuss how it can be seen as part of the wider rise and fall of management ideas.

\section{Organizational knowledge}

Organizational knowledge as a subject of study has been around for a long time, but primarily within the economics community. Thus, as we have noted above, the 'classical' influence of economists such as Hayek and Penrose, and the philosopher Polanyi, has been significant. One of the major foundational works, also from an economics perspective, is Nelson and Winter (1982), which is particularly strong on the importance of 'tacit knowing' as a basis for individual and organizational competence. Other foundational works emerged in the early 1990s, especially from two Special Issues of the Fournal of Management Studies on knowledge work (Alvesson, 1993; Starbuck, 1992, 1993); the elaboration of six different forms of organizational knowing by Blackler (1995) was also an important foundational work.

But the key popularizing influence was Ikujiro Nonaka who produced a series of papers and a highly respected book (Nonaka and Takeuchi, 1995) that set the standard for the emergent field with a rich mixture of concepts and field data. Key ideas expounded in the book include: the notion of knowledge creation through transformations of tacit and explicit knowledge; the importance of national culture and philosophy for understanding the construction and communication of knowledge; the interrelationship between the policy domain and the operational levels in the creation of knowledge; and the general principle that most dichotomies, such as tacit/explicit and mind/body, are false.

Given the importance of Nonaka's work, it is to be expected that he should attract his share of criticism. For example, there are suggestions that he misunderstands the nature of tacit knowledge, that his methodology is flawed and that his theory is not adequately supported by the evidence available (Gourlay, 2006). Nonaka has responded robustly to these criticisms through both restating the main principles of his theory and introducing new research results (Nonaka, von Krogh, and Voelpel, 2006; Nonaka and von Krogh, 2009). 
In the background, the influence of Polanyi remains strongly evident in the works of dominant figures like Nelson and Winter (1982) and Nonaka; his ideas are also central to debates about the nature of organizational knowledge (Spender, 1996) in this Handbook by von Krogh (Chapter 19) and Tsoukas (Chapter 21). But it is also possible to see the influence of Hayek and other neo-classical economists in Nonaka's discussion about the problem of resolving the perspectives of the policy and operational domains, which can be solved, Nonaka argues, through the process of knowledge conversion.

\section{Knowledge management}

The idea of knowledge management arrived only in the mid 1990s, and is still developing (Alavi and Denford, Chapter 6). Its early evolution was rapid and chaotic, even though it has settled down with some distinctive themes over the last decade. To some extent, knowledge management gained academic legitimacy on the back of Nonaka's work; the driving force in the corporate world, however, has come from major consultancy companies seeking to capitalize on the enormous potential of information technology in a period following disenchantment with the methods and prescriptions of re-engineering (Hammer and Champy, 1993; Grint and Case, 1998). The idea is pretty simple, since it starts with the neo-economic view of the strategic value of organizational knowledge and then uses familiar IT software such as databases and electronic conferencing to facilitate the acquisition, sharing, storage, retrieval, and utilization of knowledge. As such, the conceptual logic follows the technical view of organizational learning as expounded by Huber (1991).

Early critiques of knowledge management initiatives were made on the grounds that they ignore the social architecture of knowledge exchange within organizations (Hansen, Nohria, and Tierney, 1999), and it is not surprising that some of these came from the 'social' school of organizational learning theorists (for example, Brown and Duguid, 2000). In a practical sense the social perspective has adapted technologies from elsewhere (such as Facebook) into the organizational context which enables flexible communication and sharing of supposedly tacit knowledge between members (McAfee, 2006). These technologies are also being applied to the absorption of external knowledge through, for example, the creation of online user communities who provide feedback on existing products and generate new ideas for innovation (Di Ganji et al., 2010). Alavi and Denford (Chapter 6) and Hayes (Chapter 5) review the development of social networking technology over the last decade and point to some of the limitations. Some of the other chapters also discuss the role of technology in knowledge sharing, storage, and databases (see Argote, Denomme, and Fuchs, Chapter 29; Ahuja and Novelli, Chapter 25).

\section{Future Directions}

In view of the size, complexity and diversity of the field it is hard enough to come up with an encapsulation of the current state of OLKM, and even more difficult to be definitive about future directions. However, undaunted by the task, we offer here some speculation about future directions. These are based on three main sources: an informal review of current citation patterns for recently-published papers; an overview of the predictions from authors who have contributed to this Handbook; and the results of our own discussions as we have developed the Handbook. 
Our review of recent papers used ISI citation data for papers published since 2006. In this relatively short period of time, a few papers have already received over a hundred citations, and many have received over thirty. We can identify four main clusters of papers, around which recent energy has been focused, and hence which may be indicative of future trends. The strongest interest is around the drivers of corporate performance and competitive advantage. Two very influential papers (Teece, 2007; Simon, Hitt, and Ireland, 2007) examine the inner mechanisms whereby dynamic capabilities can sustain corporate performance, and Rai, Patnakayuni, and Seth (2006) and Hult et al. (2006) both look at the way knowledge can be managed in supply chains to drive competitive advantage. Other examples of well-cited papers in this area include Krishnan et al. (2006) on trust and alliance performance, and Zellmer-Bruhn and Gibson (2006) on the relation between team learning and performance in multinationals.

A second major theme is around the generation of enterprise and innovation. Zahra, Sapienza, and Davidsson (2006) provide a review and research agenda on the links between dynamic capabilities and enterprise, and Rothaermel and Hess (2007) examine how they link to innovation. Thorpe et al. (2005) look at the role of knowledge in smalland medium-sized firms. More recently both Alegre and Chiva (2008) and Liao et al. (2008) have looked at the links between organizational learning and innovation.

Our third theme is about learning and knowledge transfer between organizations. Several authors have written influential papers which both critique and develop the idea of absorptive capacity (Jansen et al., 2005; Lane et al., 2006; Todorova and Durisin, 2007). Others have conceptualized and examined the process of inter-organizational knowledge transfer (Paulraj et al., 2008; Easterby-Smith, Lyles, and Tsang, 2008; and van Wijk et al., 2008), and a third sub-group have focused on the way that learning takes place between clusters and networks of firms to produce competitive advantage (Dyer and Hatch, 2006; Lavie, 2006; Giuliani, 2007).

A fourth theme takes a more strategic perspective with examination of the interplay between exploration and exploitation especially within alliance relationships (Gupta et al., 2007; Lavie and Rosenkopf, 2006), and the way that capabilities can be built through alliances (Kale and Singh, 2007). The compromise position between exploration and exploitation is expressed in the idea of ambidexterity (Raisch and Birkinshaw, 2008; O'Reilly and Tushman, 2008).

In sum, there is strong evidence that organizational learning can impact the performance of a firm, but the problem is that this relationship may not hold at all times, and in all settings. Although we are aware of the existence of intervening variables, it is still not entirely clear which ones contribute the most, and under what circumstances, to organizational learning and performance. Consequently, this is likely to remain a research priority for a long time.

Related to this, we recognize that there is a relationship between learning and the exploitation or utilization of knowledge; yet we do not know the constructs that influence knowledge or learning utilization. Few studies address how knowledge is stored, when it is used and the timeliness of that usage. Examining real-time learning poses many difficulties beyond access to organizations and data. Exceptions exist such as those studies that evaluate how experience affects future organizational strategies. We want to understand organizational learning, but lack research on actual learning processes and knowledge. This, as several of the chapter authors imply, suggests that we should consider learning 
and knowledge as the dependent variables. Hence we might look at how social networks, communities of practice, and power structures influence knowledge and learning.

The quick and wide-spread development of emerging economies opens the door for future research addressing localized knowledge, knowledge trajectories, and outsourcing of knowledge, possibly through open innovation. Several recent papers have addressed the issues of globalization (Tsui et al., 2007; Sapienza et al., 2006), and it is due to the growing importance of cross-national learning and knowledge transfer that we have included a separate part of the Handbook on these issues. Future studies will need to consider how to build capacity for global learning, how knowledge is created, the uses of technology for knowledge transfer, the impact of social and organizational identity, and the processes of inter-organizational knowledge transfer.

\section{Conclusions}

In this opening chapter we have offered a general mapping of the field covered by the Handbook, and have also tried to demonstrate some of the inter-linkages over time and between parallel, but independent, areas of development. It has also been possible to identify some significant influences, which predate the invention of the concepts of organizational learning and knowledge management, and which might be seen as providing a common heritage, or similar watersheds.

It should be clear by now that the different sub-areas of the field are at different stages of maturity. Some of them are major rivers which have flowed gently for a long time; some are shorter streams which flow very quickly; and others are sudden torrents which emerge almost overnight — and which could disappear again equally quickly.

Several of the chapters from the first edition are now well on the way to becoming foundational works because they provide clear maps and overviews of their areas and have provided authoritative agendas for future research. As a whole, the first edition offers a major statement of the state of the field in the 'noughties' - at the start of the twenty-first century; this second edition builds on the foundational work and attempts to encapsulate the rapid development and the growing importance of the field as we enter the 'teens.'

\section{REFERENGES}

Alegre, J. and Chiva, R. (2008) Assessing the impact of organizational learning capability on product innovation performance: An empirical test. Technovation, 28(6): 315-326.

Alvesson, M. (1993) Organization as rhetoric: Knowledge-intensive firms and the struggle with ambiguity. Fournal of Management Studies, 30: 997-1016.

Argyris, C. and Schön, D.A. (1978) Organizational Learning: A Theory of Action Perspective. Reading, MA: Addison-Wesley.

Augier, M. (2001) Simon Says: Bounded rationality matters. Introduction and interview. Journal of Management Inquiry, 10(3): 268-275.

Barney, J. (1991) Firm resources and sustained competitive advantage. fournal of Management, 17(1): 99-120.

Blackler, F. (1995) Knowledge, work and organizations. Organization Studies, 16(6): 1021-1045. 
Brown, J.S. and Duguid, P. (1991) Organizational learning and communities-of-practice: Toward a unified view of working, learning and innovation. Organization Science, 2(1): 40-57.

Brown, J.S. and Duguid, P. (2000) The Social Life of Information. Boston, MA: Harvard Business School Press.

Brown, J.S. and Duguid, P. (2001) Knowledge and organization: A social-practice perspective. Organization Science, 12(2): 198-213.

Burgoyne, J., Pedler, M., and Boydell, T. (1994) Towards the Learning Company: Concepts and Practices. London: McGraw-Hill.

Cangelosi, V.E. and Dill, W.R. (1965) Organizational learning: Observations toward a theory. Administrative Science Quarterly, 10(2): 175-203.

Cook, S.D.N. and Brown, J.S. (1999) Bridging epistemologies: The generative dance between organizational knowledge and organizational knowing. Organization Science, 10(4): 381-400.

Coopey, J. (1995) The learning organization: Power, politics and ideology. Management Learning, 26(2): 193-213.

Coopey, J. and Burgoyne, J. (2000) Politics and organizational learning. Fournal of Management Studies, 37(6): 869-885.

Cyert, R.M. and March, J.G. (1963) A Behavioural Theory of the Firm. Englewood Cliffs, NJ: Prentice-Hall.

Daft, R.L. and Weick, K.L. (1984) Toward a model of organizations as interpretation systems. Academy of Management Review, 9(2): 284-295.

de Geus, A.P. (1988) Planning as learning. Harvard Business Review, 66(2): 70-74.

Dewey, J. (1916) Democracy and Education: An Introduction to the Philosophy of Education. London: Collier-Macmillan.

Di Ganji, P.M., Wasko, M.M. and Hooker, R.E. (2010) Getting customers' ideas to work for you: Learning from Dell how to succeed with online user communities. MIS Quarterly Executive, 9(4): 213-218.

Dixon, N. (1994) The Organizational Learning Cycle: How we can Learn Collectively. London: McGraw-Hill.

Dyer, J.H. and Hatch, N.W. (2006). Relation-specific capabilities and barriers to knowledge transfers: Creating advantage through network relationships. Strategic Management Journal, 27(8): 701-719.

Easterby-Smith, M. (1997) Disciplines of organizational learning. Human Relations, 50(9): 1085-1116.

Easterby-Smith, M., Lyles, M.A., and Tsang, E.W.K. (2008) Inter-organizational knowledge transfer: Current issues and future prospects. Fournal of Management Studies, 45(4): 661-674.

Epple, D., Argote, L., and Devadas, R. (1991) Organizational learning curves: A method for investigating inter-plant transfer of knowledge acquired through learning by doing. Organization Science, 2(1): 58-70.

Fiol, C.M. and Lyles, M.A. (1985) Organizational Learning. Academy of Management Review, 10(4): 803-813.

Garratt, B. (1987) The Learning Organization. London: Fontana.

Gherardi, S. (2006) Organizational Knowledge. The Texture of Workplace Learning. Oxford: Blackwell.

Giuliani, E. (2007) The selective nature of knowledge networks in clusters: Evidence from the wine industry. Fournal of Economic Geography, 7(2): 139-168. 
Gourlay, S. (2006) Conceptualizing knowledge creation: A critique of Nonaka's theory. fournal of Management Studies, 43(7): 1415-1436.

Grint, K. and Case, P. (1998) The violent rhetoric of re-engineering: Management consultancy on the offensive. Fournal of Management Studies, 35(5): 557-577.

Gupta, A.K., Tesluk, P.E., and Taylor, M.S. (2007) Innovation at and across multiple levels of analysis. Organization Science, 18(6): 885-897.

Hammer, M. and Champy, J. (1993) Reengineering the Corporation: A Manifesto for Business Revolution. London: Nicholas Brealey.

Hansen, M.T., Nohria, N., and Tierney, T. (1999) What's your strategy for managing knowledge? Harvard Business Review, 77: 106-116.

Hayek, F.A. (1945) The use of knowledge in society. In F. A. Hayek (Ed), Individualism and Economic Order. London: Routledge and Kegan Paul: 1949.

Hedberg, B. (1981) How organizations learn and unlearn. In P.C. Nystrom and W.H. Starbuck (eds.), Handbook of Organizational Design. London: Cambridge University Press.

Huber, G.P. (1991) Organizational learning: The contributing processes and the literature. Organization Science, 2(1): 88-115.

Hult, G.T.M., Ketchen, D.J., Cavusgil, S.T., and Calantone, R.J. (2006) Knowledge as a strategic resource in supply chains. Fournal of Operations Management, 24(5): 458-475.

Jansen, J., Van den Bosch, F.A.J., and Volberda, H.W. (2005) Managing potential and realised absorptive capacity: how do organizational antecedents matter? Academy of Management fournal, 43(6): 999-1015.

Kale, P. and Singh, H. (2007) Building firm capabilities through learning: The role of the alliance learning process in alliance capability and firm-level alliance success. Strategic Management fournal, 28(10): 981-1000.

Kogut, B. and Zander, U. (1992) Knowledge of the firm, combinative capabilities, and the replication of technology. Organization Science, 3(3): 383-397.

Krishnan, R., Martin, X., and Noorderhaven, N.G. (2006) When does trust matter to alliance performance? Academy of Management fournal, 49(5): 894-917.

Lane, P.J., Koka, B., and Pathak, S. (2006) The reification of absorptive capacity: A critical review and rejuvenation of the construct. Academy of Management Reviewe, 31(4): 833-863.

Lave, J. and Wenger, E. (1991) Situated Learning: Legitimate Peripheral Participation. Cambridge: Cambridge University Press.

Lavie, D. (2006) The competitive advantage of interconnected firms: An extension of the resource-based view. Academy of Management Review, 31(3): 638-658.

Lavie, D. and Rosenkopf, L. (2006) Balancing exploration and exploitation in alliance formation. Academy of Management fournal, 49(4), 797-818.

Lawrence, T.B, Mauws, M.K., Dyck, B., and Kleysen, R.F. (2005) The politics of organizational learning: Integrating power into the 4I framework. Academy of Management Review, 30(1): 180-191.

Liao, S.H., Fei, W.C., and Liu, C.T. (2008) Relationships between knowledge inertia, organizational learning and organization innovation. Technovation, 28(4): 183-195.

March, J.G. (1988) Decisions and Organizations. Oxford: Blackwell.

March, J.G. (1991) Exploration and exploitation in organizational learning. Organization Science, 2(1): 71-87.

March, J.G. and Simon, H.A. (1958) Organizations. New York: John Wiley \& Sons. 
McAfee, A.P. (2006) Enterprise 2.0: The dawn of emergent collaboration. Sloan Management Review, 47(3): 21-28.

Nelson, R.R. and Winter, S.G. (1982) An Evolutionary Theory of Economic Change. Cambridge, Mass: Harvard University Press.

Nicolini, D. and Meznar, M.B. (1995) The social construction of organizational learning: Concepts and practical issues in the field. Human Relations, 48(7): 727-746.

Nonaka, I. and Takeuchi, H. (1995) The Knowledge-Creating Company: How Japanese Companies Create the Dynamics of Innovation. Oxford: Oxford University Press.

Nonaka, I. and von Krogh, G. (2009) Tacit knowledge and knowledge conversion: Controversy and advancement in organization knowledge creation theory. Organization Science, 20(3): 635-652.

Nonaka, I., von Krogh, G., and Voelpel, S. (2006) Organizational knowledge creation theory: Evolutionary paths and future advances. Organization Studies, 27(8): 1179-1208.

O'Reilly, C.A. and Tushman, M.L. (2008) Ambidexterity as a dynamic capability: Resolving the innovator's dilemma. Research in Organizational Behavior, 28: 185-206.

Örtenblad, A. (2004) The learning organization: towards an integrated model. The Learning Organization, 11(2): 129-144.

Paulraj, A., Lado, A.A. and Chen, I.J. (2008) Inter-organizational communication as a relational competency: Antecedents and performance outcomes in collaborative buyersupplier relationships. Fournal of Operations Management, 26(1): 45-64.

Pedler, M., Boydell, T., and Burgoyne, J.G. (1989) Towards the learning company. Management Education and Development, 20(1): 1-8.

Penrose, E.T. (1959) The Theory of the Growth of the Firm. Oxford: Blackwell.

Peters, T.J. and Waterman, R.H. (1982) In Search of Excellence: Lessons from America's Best Run Companies. New York: Harper and Row.

Polanyi, M. (1966) The Tacit Dimension. London: Routledge and Kegan Paul.

Rai, A., Patnayakuni, R., and Seth, N. (2006) Firm performance impacts of digitally enabled supply chain integration capabilities. MIS Quarterly, 30(2): 225-246.

Raisch, S. and Birkinshaw, J. (2008) Organizational ambidexterity: Antecedents, outcomes, and moderators. Fournal of Management, 34(3): 375-409.

Revans, R.W. (1980) Action Learning: New Techniques for Management. London: Blond and Briggs.

Rothaermel, F.T. and Hess, A.M. (2007) Building dynamic capabilities: Innovation driven by individual-, firm-, and network-level effects. Organization Science, 18(6): 898-921.

Sapienza, H.J., Autio, E., George, G., and Zahra, S.A. (2006) A capabilities perspective on the effects of early internationalization on firm survival and growth. Academy of Management Review, 31(4): 914-933.

Senge, P.M. (1990) The Fifth Discipline: The Art and Practice of the Learning Organization. London: Century Business.

Shrivastra, P. (1983) A typology of organizational learning systems. Fournal of Management Studies, 20(1): 7-28.

Simm, D. (2009) The 'Celebritization' of a 'Learning Organization': The Case of Rover. PhD Thesis, Lancaster University.

Simon, H. (1991) Bounded rationality and organizational learning. Organization Science, 2(1): 125-134. 
Simon, D.G., Hitt, M.A., and Ireland, R.D. (2007) Managing firm resources in dynamic environments to create value: Looking inside the black box. Academy of Management Review, 32(1): 273-292.

Snell, R. and Chak, A. M-K. (1998) The learning organization: Learning and empowerment for whom? Management Learning, 29(3): 337-364.

Spender, J-C. (1996) Making knowledge the basis of a dynamic theory of the firm. Strategic Management fournal, 19: 45-62.

Starbuck, W.H. (1992) Learning by knowledge-intensive firms. Fournal of Management Studies, 29: 713-740.

Starbuck, W.H. (1993) Keeping a butterfly and an elephant in a house of cards: The elements of exceptional success. Fournal of Management Studies, 30: 885-922.

Swieringa, J. and Wierdsma, A. (1992) Becoming a Learning Organization: Beyond the Learning Curve. Wokingham, England: Addison-Wesley.

Teece, D.J. (2007) Explicating dynamic capabilities: The nature and microfoundations of (sustainable) enterprise performance. Strategic Management fournal, 28(13): 1319-1350.

Teece, D.J., Pisano, G., and Shuen, A. (1997) Dynamic capabilities and strategic management. Strategic Management fournal, 18(7): 509-533.

Thomas, K. and Allen, S. (2006) The learning organization: A meta-analysis of themes in literature. The Learning Organization, 13(2): 123-139.

Thorpe, R., Holt, R., Macpherson, A., and Pittaway, L. (2005) Using knowledge within small and medium-sized firms: A systematic review of the evidence. International fournal of Management Reviews, 7(4): 257-281.

Todorova, G. and Durisin, B. (2007) Absorptive capacity: Valuing a re-conceptualization. Academy of Management Review, 32(3): 774-786.

Torbert, W.R. (1994) Managerial learning, organizational learning: a potentially powerful redundancy. Management Learning, 25(1): 57-70.

Tsang, E.W.K. (1997) Organizational learning and the learning organization: A dichotomy between descriptive and prescriptive research. Human Relations, 50(1): 73-89.

Tsui, A.S., Nifadkar, S.S., and Ou, A.Y. (2007) Cross-national, cross-cultural organizational behavior research: Advances, gaps, and recommendations. Fournal of Management, 33(3): 426-478.

Van Wijk, R., Jansen, J.P., and Lyles, M.A. (2008) Inter- and intra-organizational knowledge transfer: A meta-analytic review and assessment of its antecedents and consequences. Journal of Management Studies, 45: 815-838.

Wenger, E. (1998) Communities of Practice: Learning, Meaning, and Identity. Cambridge: Cambridge University Press.

Yeo, R.K. (2005) Revisiting the roots of learning organization: a synthesis of the learning organization literature. The Learning Organization, 12(4): 368-382.

Zahra, S.A., Sapienza, H.J., and Davidsson, P. (2006) Entrepreneurship and dynamic capabilities: A review, model and research agenda. Fournal of Management Studies, 43(4): 917-955.

Zellmer-Bruhn, M. and Gibson, C. (2006) Multinational organization context: Implications for team learning and performance. Academy of Management fournal, 49(3): 501-518. 